\title{
Characteristics and Management Plan for the Distribution of Nelumbo nucifera community in Junam Wetland
}

\author{
Soo-Dong Lee ${ }^{1 *}$, Han $\mathrm{Kim}^{2}$, Bong-Gyo $\mathrm{Cho}^{3}$, and Gwang-Gyu Lee ${ }^{4}$ \\ ${ }^{1}$ Professor, Department of Landscape Architecture, Gyeongsang National University, Jinju-si, Gyeongsangnam-do 52725, Korea \\ ${ }^{2}$ Researcher, National Institute of Ecology, Seocheon, 33657, Korea \\ ${ }^{3}$ Doctoral Student, Gyeongsang National University, Jinju-si, Gyeongsangnam-do 52725, Korea \\ ${ }^{4}$ Researcher, National Research Institute of Cultural Heritage, Natural Cultural Properties Lab., Dajeon-si, 34122, Korea
}

\section{ABSTRACT}

Background and objective: If the Nelumbo nucifera spreads in a wetland at a high density, it can have considerable positive and negative ecological effects on habitats. For this reason, it is necessary to precisely investigate the impacts of its rapid proliferation. This study was conducted to propose the distribution and management of $N$. nucifera, which can cause the degradation of wildlife habitats due to the rapid spread of internal and external environmental factors that may affect the Junam wetland ecosystem.

Methods: For the investigation and analysis of physical and ecological characteristics, factors of the abiotic environment such as general weather conditions, topography and water depth structure, and soil and water quality analysis, and bioenvironment characteristics such as changes in the $N$. nucifera community distribution were evaluated. To assess whether the differences in the soil depth and physicochemical characteristics between the $N$. nucifera community and the aquatic plant community are statistically significant, a One-way ANOVA was executed.

Results: N. nucifera was presumably introduced in approximately 2007 and observed at a prevalence of only $0.8 \%$ in 2009 , but had expanded to $11.1 \%$ in 2014. After that, the area was increased to $19.3 \%$ in 2015 and $40.0 \%$ in 2017 , about twice that of the previous survey year. The rapid diffusion of an $N$. nucifera colony can have adverse effects on wildlife habitats and biodiversity at Junam Wetland. To solve these problems, four management methods can be proposed; water level management, mowing management, installation of posts and removal of lotus roots. Control of the $\mathrm{N}$. nucifera community using these methods was judged to be suitable for cutting and water level management when considering expansion rate, water level variation, and wildlife habitat impacts.

Conclusion: As the biotic and abiotic environmental factors are different for each wetland, it is necessary to determine the timing and method of management through a detailed investigation.

Keywords: aquatic plants, biodiversity, environmental risk, water level management, wetland ecosystem

\section{Introduction}

A wetland is a transitional ecosystem that connects the water surface, vegetation zone, and land, and is highly involved in water purification, habitat provision, biodiversity maintenance, and water supply, which are significant concerns for humans. Wetlands are important ecosystems that fulfill numerous functions and roles (Bellrose, 1980; Mitshc and Gooselink, 2000;
Van der Valk, 2012). Yet in spite of their importance, wetlands are continuously threatened by the development of basin zones, landfill, the influx of pollutants, and the invasion and proliferation of exotic species, which have had fatal effects on the survival of wetland-dependent species (Bellrose et al., 1983; Illinois Wildlife Habitat Commission, 1985). Wetland deterioration adversely affects biodiversity, as well as reducing stopover sites, breeding sites, and foraging sites for migratory

Received: May 18, 2021, Revised: June 15, 2021, Accepted: August 25, 2021

First author: Soo-Dong Lee, ecoplan@gnu.ac.kr, (10) https://orcid.org/0000-0003-4893-8850

*Corresponding author: Soo-Dong Lee, ecoplan@gnu.ac.kr, (1) https://orcid.org/0000-0003-4893-8850 
birds (Myers et al., 1987; King et al., 2000; Naugle et al., 2000). While aquatic plants play an important role in feeds, spawning, and hiding (Weller, 1999), a high-density N. mucifera community can damage biodiversity by interfering with the growth and development of other species or by distorting the water flow (Bini et al., 1999). For this reason, the monitoring and management of the internal and external environmental factors that cause qualitative degradation are essential prerequisites for sustaining their ecological values.

Although the $N$. nucifera has aesthetic value and religious significance in both the East and the West (Kim, 2012), if it spreads at a high density in the wetland, it can create substantial ecological issues for habitats, so it is necessary to precisely investigate the impacts of its rapid proliferation. $N$. mucifera is a perennial aquatic plant, and about eight genera and dozens of species are widely distributed in tropical and temperate eastern Asia, the Caspian Sea to the west, and Korea and Japan to the east (Li et al., 2014). In Korea, it grows in ponds, paddy fields, and swamps throughout the country where the average daily temperature is $15^{\circ} \mathrm{C}$ or higher for 6 months or more, except in the cold northern regions (Kim, 2008). In general, plants with the characteristics of floating-leaved life forms thrive successfully in stagnant or slow-flowing silt deposits at depths of about 0.5 to $3.5 \mathrm{~m}$ (Sculthorpe, 1967). For $N$. nucifera, a clay base with a water depth of around $20 \mathrm{~cm}$ is insufficient for cultivating lotus roots (Kang, 2006), but in its natural state, it can grow at depths of $3 \mathrm{~m}$ or more (Unni, 1971; Nohara and Kimura, 1997; Kuni and Maeda, 1982). The habitat and water depth of $N$. mucifera can penetrate even in deep water depending on resource availability, disturbance intensity, floating leaf reproduction cost, and energy accumulation during growth (Grime, 1979). In particular, it has been reported that the water level fluctuation and the intensity of flooding were closely related not only to the growth but also to the composition of coexisting wetland plant species (Nohara and Tsuchiya, 1990; Brock et al, 2003). On the other hand, heterophylly of leaves within the same plant is common in aquatic plants (Sculthorpe, 1967). Emergent aquatic plants tend to dominate other wetland plants because the emergent leaves create shade at shallow water depths and the aerial leaves create shade over deep waters (Bini et al., 1999). By blocking light transmission, other species are prevented from growing. Since N. nucifera is a species included in this group, it was judged that management was necessary.

Meanwhile, Junam wetland, which was previously composed of rice paddies and natural wetlands, now has 3 artificial reservoirs established, including Junam, Dongpan and Sannam reservoir, due to the embankment construction in the 1920s. Although it is a constructed wetland, it still requires special protection and management owing to its high level of importance as a habitat with the emergence of 18 wildlife species that are on the brink of extinction including Grus vipio, Cygmus cygmus, C. columbiamus, Platalea minor and Ciconia boyciana, as well as 85 waterfowl species (Hahm, 1997; 2000). However, in spite of its importance as a wintering site, there has been increase in internal and external damages as well as pressure for development, including plans for the construction of an industrial area and urban center, which has led to the covering up of rice paddies with soil, the influx of pollutants, the dispersion of the N. nucifera community, arbitrary control of water levels and conflict with the fishery. Such disturbances are leading to secondary damages, including a reduction in the diversity of aquatic plant species, eutrophication, damages to the roosting sites for the wintering wild birds, and a reduction in rice paddies, which are foraging sites, indicating that urgent management is needed.

While a previous study found that the $N$. mucifera community, which is spreading in reservoirs, is irrelevant to the wintering environment damage as it provides feeds to $C$. cygnus (Hong and An, 2016), the findings of this study did not presume the circumstance in which the entire water's surface is covered by the plant. Wetlands with shallow depth require management, as coverage of the entire water's surface by vegetation not only interferes with the habitation of wildlife but also induces water quality degradation (Weller, 1999). While Junam wetland plays a core role as breeding ground and wintering site (Hahm, 1997), there have been concerns that a rapid increase in the dispersion area of $N$. nucifera will lead to a reduction in biodiversity and a deterioration of habitat for wild birds along with the pressure to develop the rice paddies into other purpose facilities. Accordingly, this study was carried out to propose methods of controlling the $N$. nucifera community that will not induce adverse effects on the wetland environment, along with a comprehensive review of the risks that can occur due to its dispersion. 


\section{Research Methods}

\section{Overview of study site and present conditions}

In this study, Junam wetland will refer to the area that includes not only the Junam, Dongpan, and Sannam reservoirs but also the rice paddies used as foraging sites situated between these reservoirs and Nakdong river. Reservoirs are the areas inside an embankment in which water surface and aquatic plants are distributed, and the term is used when indicating each of the ones within the Junam wetland. The survey site is located in Dong-eup in Changwon-si (Fig. 1), covering the general regions with coordinates of $35^{\circ} 18^{\prime} 46^{\prime \prime}$ north latitude and $128^{\circ} 39^{\prime}$ 55" east longitude.

The Junam wetland has Geumbyeong Mt. (271 m), Jeongbyeong Mt. (566 m), Guryong Mt. (433 m), and Baegwol Mt. (300 m)

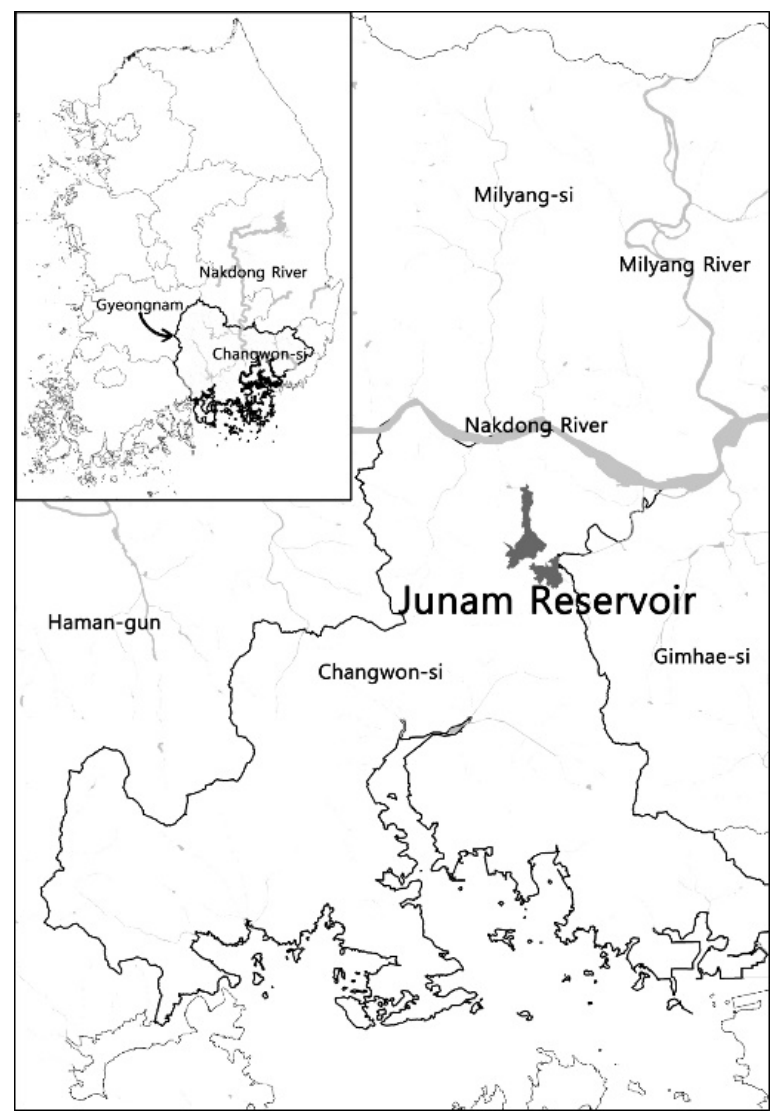

The grey line is Nakdong river, and the black line is the provincial boundary.

Fig. 1. Survey site location. Junam wetland is located between Nakdong river and the city of Changwon. as the boundary line in its surroundings (Park et al., 2012). Although it had been a swamp maintained due to the overflowing of the Nakdong river, it was converted into an agricultural reservoir after the construction of a dike in the 1920 s (www.ngii.go.kr; Changwon, 2018). Currently, it is serving as a background wetland for Nakdong river, inhabited by various aquatic plants and migratory birds. Extensive rice paddies are formed around the reservoir that serve as resting sites, food supply and migration route for birds, and have been evaluated as a wintering site for migratory birds in the southern inland with good habitat at par with the downstream basin of Nakdong river, which is designated as Natural Monument No. 179 of Korea (Hahm, 2000). However, in terms of protection, it has been designated as a site of the East AsianAustralasian Flyway Partnership (EAAFP), but it is not registered as a Ramsar Wetland or a protected wetland area, so there are no legal or institutional protection measures. From an administration perspective, it is being left unattended and is confronted with an extensive range of internal problems including an elevated diffusion and expansion of $N$. mucifera community and pressure to develop rice paddies, which are foraging sites. Accordingly, this study will comprehensively review the risks arising from the rapid dispersion of $N$. nucifera community in order to propose efficient means of managing the factors that damage the wetland.

\section{Data collection and analysis}

Among the internal and external environmental damaging factors capable of affecting the wetland ecosystem, the research was conducted to examine the distribution characteristics of $N$. nucifera, which can induce degradation of the habitat for wildlife due to its rapid dispersion, and how to control such proliferation. This study was divided into three stages: investigation and analysis of the physical and habitat characteristics of the $N$. nucifera community distribution area within the reservoir, comprehensive risk analysis, and management method presentation.

Various environmental factors must be prepared for the stable distribution of $N$. micifera, but temperature, wetland water depth, and soil conditions have the greatest influence (Choi, 2009). Accordingly, the ecological characteristics survey and analysis of Junam wetland identified abiotic environmental factors such 
as climate and weather conditions, topography and water depth structure, soil and water quality, and biological environmental characteristics such as distribution patterns of $N$. nucifera community according to time-series changes. Data from Changwon Meteorological Observation Center (www.kma.go.kr) was utilized to ascertain the changes in the monthly rainfall. The pattern of changes was confirmed by comparatively analyzing the rainfall over the last 20 years (1998-2017). The water depth drawing was mapped based on the determination that it is essential for the expansion of $N$. nucifera community and efficient management of the wetland, which is the wintering site for wild birds (Hong and An, 2016), and for the establishment of a foundation for long- term monitoring thereof. After having determined the water depth at each of the designated points using Sokkia GSX2, a GPS measuring tool for the discernment of locational information, and with a depth measuring rod, it was mapped using the Surf program. Surveys on the water depth were conducted at 1,574, 1,288 and 626 points for the Junam, Dongpan, and Sannam reservoir, respectively, over the 5 days of April 29 (3.82 m), April 30 (3.82 m), May $8(3.76 \mathrm{~m})$, May $13(3.77 \mathrm{~m})$ and June 2 $(3.02 \mathrm{~m})$. The measurements were adjusted in accordance

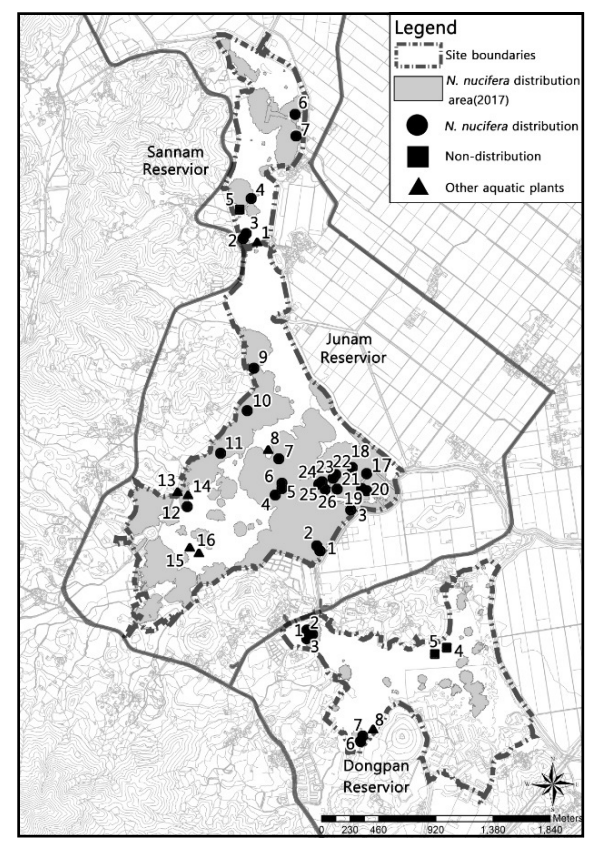

Symbols are explained in the legend.

Fig. 2. Soil sampling points in each layer within Sannam, Junam, and Dongpan Reservoir. with the standard water level $(3.82 \mathrm{~m})$ as of April 29.

To assess the changes in the soil and water quality environment in accordance with the proliferation of the $N$. mucifera community, samples were collected by dividing into the $N$. nucifera distribution area, non-distribution area, and other aquatic plants community (Fig. 2, Fig. 3). The soil was classified into surface soil and subsoil according to the color or hardness of the top layer that has recently been deposited and the existing soil stratum in order to check the extent of sedimentation for each location. The depth of sample collection was quite varied $(20-70 \mathrm{~cm})$ due to the heterogeneity in water depth and soil hardness. Soil samples were dried in shade indoors and sieved through a $2 \mathrm{~mm}$ strainer to analyze the soil acidity $(\mathrm{pH})$, electrical conductivity (EC), microbial activation, available phosphorous, and exchangeable cation ( $\mathrm{Ca}, \mathrm{Mg}, \mathrm{K}, \mathrm{Na}$ ). To determine whether the differences in the soil depth and physicochemical characteristics between the $N$. nucifera community and the aquatic plant community are statistically significant, the One-way ANOVA was executed, and Welch's ANOVA was executed for the items that failed to pass the assumption of covariance. To confirm the differences between the soil strata, a post-hoc test was exe-

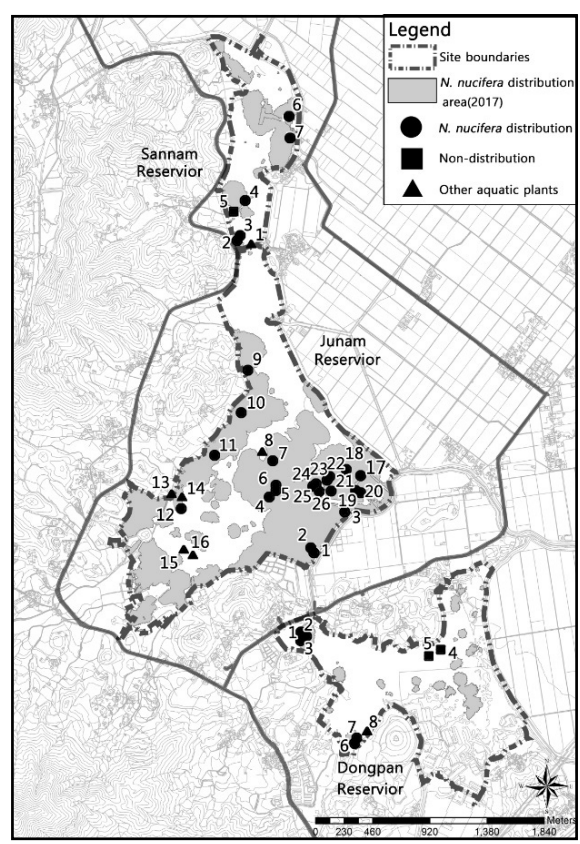

Symbols are explained in the legend.

Fig. 3. Water sampling points within Sannam, Junam, and Dongpan Reservoir. 
cuted using the R3.6.1 program. Based on the presumption that the water quality will be highly correlated with the water flow, water samples were collected in consideration of the depth and density of the aquatic plants. The water quality research center of Gyeongnam National University of Science and Technology was requested to perform an analysis. Water quality test items included biological oxygen demand (BOD), chemical oxygen demand (COD), suspended solid (SS), total nitrogen (TN) and total phosphate (TP), and the Ministry of Environment's standards for water pollution process test were complied with.

N. nucifera community distribution was obtained by recomposing the data of aerial photographs for 2009 and 2011 (Daum and Google map), Hong and An (2016) for 2013 and 2014, and GRETeC for 2015 (2015) to assess the tendency in the expansion thereof. In 2017, photographs were taken with a drone (DJI Phantom Pro) and a distribution map was produced. Management methods are proposed on the basis of the actual management cases in Korea (Nakdong river Basin Environmental Office 2016), and the research results of Nohara and Tsuchiya (1990), Ashizawa et al. (2015) and Shimada et al. (2017).

To propose the final management plan for the lotus community, in the first stage, we tried to understand the risks to the wetland ecosystem as well as its ecological characteristics through a comparison and analysis of changes in distribution area by year, water depth, soil, and water quality of distribution and non-distributed control areas. In the second stage, a management plan was proposed based on these comprehensive analysis data.

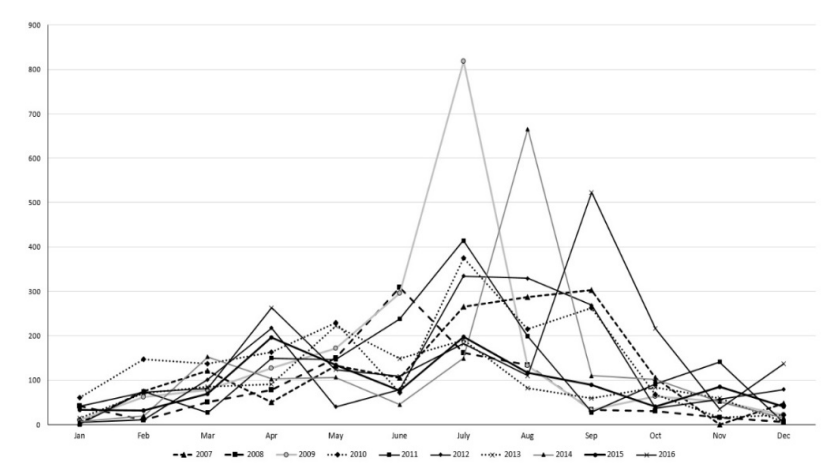

Fig. 4. Monthly precipitation change trend for 20 years (1998-2017) at Changwon Meteorological Observation Center.

\section{Results}

\section{Weather conditions}

Through the climate condition review, it was found that it displayed a tendency similar to the 30-year average values (1981-2010) with 60-70\% of rainfall concentrated during the summer (June-September). Figs. 4 and 5 showed that the original water level was restored naturally due to heavy rainfall after having been supplied for agricultural uses during April-May, which is the busiest farming season prior to 2012. However, after 2012, there was a lack of precipitation during May-June, and it is presumed that a shallow water depth environment, which is appropriate for the growth of N. nucifera, was maintained without any natural replenishment of water through heavy rainfall. Therefore, without artificial water supply during the time of insufficient precipitation, it is judged that the possibility of $N$. nucifera dispersion will increase due to maintenance of a water depth of less than $1.5 \mathrm{~m}$.

\section{Water quality}

According to the results of a water quality analysis of the $N$. nucifera community and the aquatic plant community (Table 1, Fig. 6), pH of 7.5 (7.0-7.8), BOD of 2.53 (1.4-7.0) $\mathrm{mg} \cdot \mathrm{L}^{-1}, \mathrm{COD}$ of $19.00(12.2-84.2) \mathrm{mg} \cdot \mathrm{L}^{-1}, \mathrm{SS}$ of 71.82 (9.6-998.0 mg $\cdot \mathrm{L}^{-1}, \mathrm{~T}-\mathrm{N}$ of $2.814(0.766-13.956) \mathrm{mg} \cdot \mathrm{L}^{-1}$ and T-P of $0.115(0.025-0.335) \mathrm{mg} \cdot \mathrm{L}^{-1}$ were obtained. Compared to the standards of the Ministry of Environment (www.wamis.go.kr/wke/wke_wqbase_lst.aspx), BOD was found to be slightly good, COD and SS were poor, and TN and

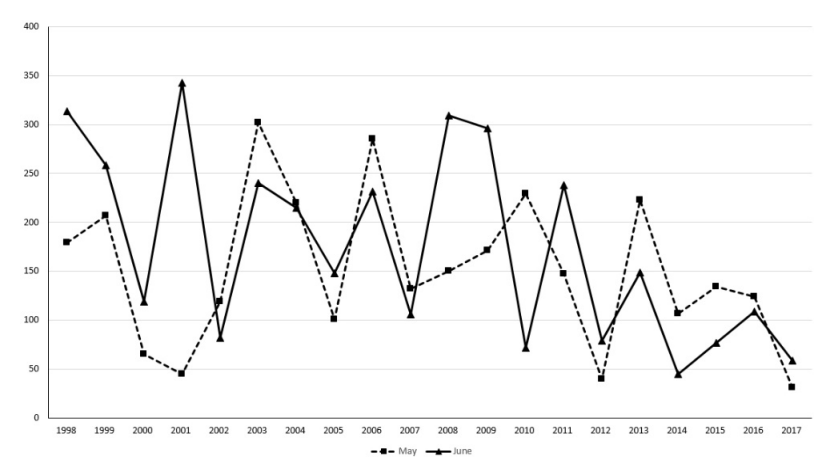

Fig. 5. Changes in precipitation in May and June at Changwon Meteorological Observation Center. 
Table 1. Current water quality status of Nelumbo nucifera community and aquatic plant community in each reservoir

\begin{tabular}{|c|c|c|c|c|c|c|c|}
\hline \multicolumn{2}{|c|}{ Classification } & $\mathrm{pH}$ & BOD & COD & SS & $\mathrm{T}-\mathrm{N}$ & T-P \\
\hline \multirow{3}{*}{ Total } & Average & $7.5(7.0-7.8)$ & $2.53(1.4-7.0)$ & $19.00(12.2-84.2)$ & $71.82(9.6-998.0)$ & $2.814(0.766-13.956)$ & $0.115(0.025-0.335)$ \\
\hline & Aquatic plant & $7.5(7.2-7.8)$ & $2.96(1.5-4.6)$ & $16.24(13.5-18.8)$ & $35.04(9.6-101.4)$ & $3.222(1.085-8.328)$ & $0.121(0.059-0.235)$ \\
\hline & Lotus & $7.5(7.0-7.7)$ & $2.75(1.4-7.0)$ & $20.84(12.2-84.2)$ & $96.33(10.0-998.0)$ & $2.542(0.766-13.956)$ & $0.111(0.025-0.335)$ \\
\hline Junam & Aquatic plant & 7.6 & 2.73 & 16.03 & 22.97 & 1.97 & 0.08 \\
\hline Reservoir & Lotus & 7.5 & 2.64 & 15.93 & 26.75 & 1.49 & 0.10 \\
\hline Dongpan & Aquatic plant & 7.4 & 3.30 & 16.55 & 53.15 & 5.10 & 0.18 \\
\hline Reservoir & Lotus & 7.3 & 3.17 & 40.50 & 374.67 & 6.73 & 0.16 \\
\hline
\end{tabular}

BOD: biological oxygen demand, COD: chemical oxygen demand, SS: suspended solid, T-N: total nitrogen, T-P: total phosphate.

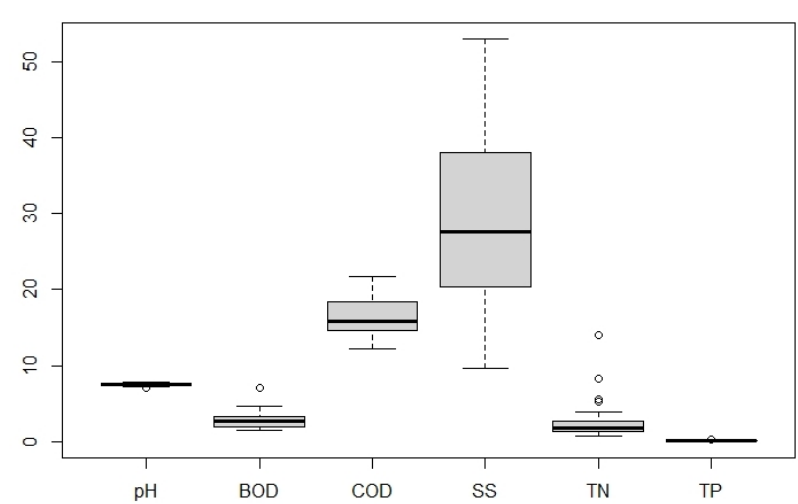

Fig. 6. The average water quality analysis result of Junam wetland.

TP were average or poor. Looking at each analysis item (Table 1), $\mathrm{pH}$ was the same at 7.5, while BOD, T-N, and T-P, and COD and SS were low for the N. micifera community and for the aquatic plant community. When examined in terms of the location, BOD, COD, and T-N, and SS and T-P were low for both the $N$. nucifera community and the aquatic plant community in the Junam reservoir. For the Dongpan reservoir, BOD and T-P, and COD, T-N, and SS were low both for the $N$. nucifera community and for the aquatic plant community. According to the One-way ANOVA analysis results (p-values 0.4258-0.7397, confidence level of 95\%), there is no difference in the average between the 2 groups. But the area where the $N$. nucifera is distributed is judged to need improvement because the water quality is generally at a poor level due to stagnation.

\section{Soil environment}

\section{Layer structure}

The depth of the subsoil was estimated on the basis of the Sannam reservoir, which was temporarily excavated to establish a fish spawning ground, and was found to be more than $1.5 \mathrm{~m}$. In the case of Junam reservoir, although there was no difference in the averages of top layer and subsoil, surface soil was deeper for the $N$. nucifera community, at $12.6 \mathrm{~cm}$. Even though the depth of subsoil in the Dongpan reservoir was similar, the depths of the top layer and the surface soil of the aquatic plant community were $2.4 \mathrm{~cm}$ and $14.3 \mathrm{~cm}$, respectively, while those of the $N$. nucifera community were relatively deeper, at $7.8 \mathrm{~cm}$ and $19.5 \mathrm{~cm}$ (Table 2). In the Sannam reservoir, the location 1 at which Paspalum distichum is predominant (refer to Fig. 3) is an area with stagnant water. However, with the exception of the fact that the surface soil is $14 \mathrm{~cm}$ due to the accumulation of sludge and sediment, there was no difference in the depth in comparison to the $N$. nucifera and the aquatic plant community.

Table 2. Depth of soil layer difference between Nelumbo nucifera community and aquatic plant community in each reservoir

\begin{tabular}{|c|c|c|c|c|}
\hline Reservoir & Classification & $\begin{array}{c}\text { Top layer } \\
(\mathrm{cm})\end{array}$ & $\begin{array}{l}\text { Suface layer } \\
(\mathrm{cm})\end{array}$ & Subsoil layer $(\mathrm{cm})$ \\
\hline \multirow{2}{*}{ Junam } & Aquatic plant & $3.7(0-10)$ & $7.2(0-10)$ & $\geq 50$ \\
\hline & Lotus & $3.5(0-33)$ & $12.6(0-34)$ & $\geq 50$ \\
\hline \multirow{3}{*}{ Dongpan } & Non vegetation & - & 25 & $\geq 50$ \\
\hline & Aquatic plant & $2.4(0-5)$ & $14.3(4-20)$ & $\geq 50$ \\
\hline & Lotus & $7.8(5.5-10)$ & $19.5(11-28)$ & $\geq 50$ \\
\hline \multirow{3}{*}{ Sannam } & $\begin{array}{c}\text { Paspalum } \\
\text { distichum Comm. }\end{array}$ & 14 & 36 & - \\
\hline & Aquatic plant & - & 11 & $\geq 50$ \\
\hline & Lotus & - & $20.3(17-22)$ & $\geq 50($ partly $\geq 150)$ \\
\hline
\end{tabular}


In terms of the top layer (p-value 0.0016), it was statistically acknowledged that the $N$. nucifera community had greater depth than the aquatic plant community, but the difference in the depth of the surface soil ( $p$-value 0.4985 ) could not be confirmed. The top layer of the $N$. nucifera community had a greater depth than those in the regions without aquatic plants or vegetations. This is deemed to be the result of sedimentation of water plant wastes, fruits and other suspended solids due to the stagnation of the water around the plant stems.

\section{Chemical characteristics}

Chemical characteristics of the soil included $\mathrm{pH}$ of 7.47.5, EC of $0.68-4.01 \mathrm{dS} \cdot \mathrm{m}^{-1}, \mathrm{Mg}$ of $0.141-0.252 \mathrm{cmol} \cdot \mathrm{kg}^{-1}$, $\mathrm{Na}$ of $0.576-0.754 \mathrm{cmol} \cdot \mathrm{kg}^{-1}, \mathrm{~K}$ of $0.327-0.739 \mathrm{cmol} \cdot \mathrm{kg}^{-1}$, $\mathrm{Ca}$ of 3.226-6.389 $\mathrm{cmol} \cdot \mathrm{kg}^{-1}$, microbial contents (DHA) of $27.6-2,699.2 \mathrm{mg} \cdot \mathrm{g}^{-1}$ and available phosphorous of $0.0-2.0$ $\mathrm{mg} \cdot \mathrm{g}^{-1}$ (Table 3). $\mathrm{pH}$ is alkaline, and $\mathrm{EC}$, with the exclusion of the subsoil of Junam and Dongpan reservoir, is found to be more than $1.5 \mathrm{dS} \cdot \mathrm{m}^{-1}$ in most cases, conditions that are disadvantageous for absorption of nutrients. Among the cation exchange capacities, $\mathrm{Mg}$ and $\mathrm{Ca}$ were lower than the standard, but $\mathrm{Na}$ and $\mathrm{K}$ were higher. Available phosphorous was substantially lower than the standards in the range of 11-60 $\mathrm{mg} \cdot \mathrm{kg}^{-1}$, which is deemed to be the result of a longer period of sedimentation as one goes deeper into the subsoil.

There are significant differences in EC, DHA and Avail-P between the surface soil and the subsoil (Table 4, Fig. 7). The p-values of $\mathrm{pH}, \mathrm{BOD}, \mathrm{COD}, \mathrm{SS}, \mathrm{TN}$, and TP were in the range of 3.67e-07-0.0115 at a confidence level of $95 \%$. As such, it was possible to dismiss the hypothesis that there is no difference in the average between the two groups. However, in the case of $\mathrm{Mg}$, $\mathrm{p}$-value was 0.22 , resulting in the assumption that there is no difference for each strata. Having categorized the sedimentary layer into the top layer, surface soil, and subsoil, it was analyzed that there are differences in the chemical characteristics between the top layer, which is the layer deposited last, and the surface soil and subsoil, which are existing sedimentation layers but with temporal differences.

\section{Current status of water depth and $N$. nucifera community distribution}

An analysis of the annual area change of the N. nucifera community based on the relationship with water depth showed a tendency to spread from shallow to deep water. $19.62 \%$, $15.41 \%, 12.28 \%$ and $10.02 \%$ were in the depth ranges of 1.4 $1.6 \mathrm{~m}, 1.6-1.8 \mathrm{~m}, 1.2-1.4 \mathrm{~m}$, and 1.0-1.2 m, respectively, with the widest expansion being $20.56 \%$ at a depth of less than $1.0 \mathrm{~m}$ (Table 5, Fig. 8). A very narrow proliferation area of $4.63 \%$ were at a depth of more than $2 \mathrm{~m}$ and were distributed in linear format along the excavated water channel. In 2015, $6.18 \%, 5.64 \%$, and $12.63 \%$ were at depths of $1.4-1.6 \mathrm{~m}$, 1.2-1.4 $\mathrm{m}$ and less than $1.2 \mathrm{~m}$, respectively, showing that the majority flourished at a depth of less than $1.6 \mathrm{~m}$. Similarly, $12.63 \%, 9.11 \%, 15.41 \%$ and $11.75 \%$ were at depths of 1.4 $1.6 \mathrm{~m}, 1.2-1.4 \mathrm{~m}, 1.6-1.8 \mathrm{~m}$ and less than $1.2 \mathrm{~m}$, respectively, in 2017 , showing that the majority dispersed at a depth of less than $1.6 \mathrm{~m}$, as was the case in 2015 . However, this also demonstrated that expansion to depths of more than $1.6 \mathrm{~m}$ had begun.

Table 3. Results of analysis of soil chemical characteristics in each soil layer

\begin{tabular}{|c|c|c|c|c|c|c|c|c|c|}
\hline \multirow{2}{*}{ Reservoir } & \multirow{2}{*}{ Layer } & \multirow{2}{*}{$\mathrm{pH}$} & \multirow{2}{*}{$\begin{array}{c}\mathrm{EC} \\
\left(\mathrm{dS} \cdot \mathrm{m}^{-1}\right)\end{array}$} & \multicolumn{4}{|c|}{ Mineral content $\left(\mathrm{cmol} \cdot \mathrm{kg}^{-1}\right)$} & \multirow{2}{*}{$\begin{array}{c}\text { DHA } \\
\left(\mathrm{mg} \cdot \mathrm{g}^{-1}\right)\end{array}$} & \multirow{2}{*}{$\begin{array}{c}\text { Avail. P } \\
\left(\mathrm{mg} \cdot \mathrm{kg}^{-1}\right)\end{array}$} \\
\hline & & & & $\mathrm{Mg}$ & $\mathrm{Na}$ & $\mathrm{K}$ & $\mathrm{Ca}$ & & \\
\hline \multirow{3}{*}{ Junam } & Top & 7.5 & 3.14 & 0.174 & 0.587 & 0.465 & 4.726 & $1,280.8$ & 2.0 \\
\hline & Surface & 7.5 & 4.01 & 0.160 & 0.576 & 0.431 & 3.719 & 568.0 & 0.9 \\
\hline & Subsoil & 7.5 & 0.95 & 0.159 & 0.691 & 0.327 & 3.630 & 79.6 & 0.4 \\
\hline \multirow{3}{*}{ Dongpan } & Top & 7.4 & 3.56 & 0.252 & 0.733 & 0.739 & 6.389 & $2,699.2$ & 1.6 \\
\hline & Surface & 7.5 & 1.91 & 0.203 & 0.664 & 0.569 & 4.759 & 974.3 & 1.1 \\
\hline & Subsoil & 7.4 & 0.68 & 0.223 & 0.653 & 0.459 & 3.025 & 27.6 & 0.0 \\
\hline \multirow{2}{*}{ Sannam } & Surface & 7.5 & 3.12 & 0.141 & 0.621 & 0.582 & 4.293 & $1,300.4$ & 0.6 \\
\hline & Subsoil & 7.4 & 1.5 & 0.153 & 0.754 & 0.485 & 3.226 & 455.9 & 0.1 \\
\hline Kim (1999) & - & $5.6-6.8$ & $0.4-0.9$ & $1.0-5.0$ & $0.14-0.2$ & $0.1-0.5$ & $1.7-11.8$ & - & $11-60$ \\
\hline
\end{tabular}


Table 4. Analysis of One-way ANOVA by soil layer

\begin{tabular}{|c|c|c|c|c|c|c|c|c|c|}
\hline \multirow{2}{*}{ Item } & \multirow{2}{*}{ Division } & \multirow{2}{*}{ Df } & \multirow{2}{*}{ Sum Sq } & \multirow{2}{*}{ Mean Sq } & \multirow{2}{*}{ F value } & \multirow{2}{*}{$\operatorname{Pr}(>F)$} & \multirow{2}{*}{ Welch's ANOVA Pr ( > WJ ) } & \multicolumn{2}{|c|}{ Posthoc Test } \\
\hline & & & & & & & & Layer & $\operatorname{Pr}(>F)$ \\
\hline \multirow{3}{*}{$\mathrm{pH}$} & layer & 2 & 3.91 & 1.9561 & 4.68 & $0.0115 *$ & \multirow{3}{*}{-} & L_02-L_01 & 0.8450 \\
\hline & & & & & & & & L_03-L_01 & $0.0209^{*}$ \\
\hline & Residuals & 97 & 40.57 & 0.4182 & & & & L_03-L_02 & $0.0085^{* *}$ \\
\hline \multirow{3}{*}{$\mathrm{EC}$} & laver & 2 & 727494 & 363747 & 1736 & $3.67 \mathrm{e}-07 * * *$ & \multirow{3}{*}{$3.559901 \mathrm{e}-05$} & L_02-L_01 & 0.8186 \\
\hline & layer & 2 & & & 17.00 & $3.0 / \mathrm{e}-0 / \mathrm{m}$ & & L_03-L_01 & 0.0787 \\
\hline & Residuals & 96 & 2011582 & 20954 & & & & L_03-L_02 & $0.0360^{*}$ \\
\hline \multirow{3}{*}{$\mathrm{Mg}$} & layer & 2 & 0.00457 & 0.002284 & 1.54 & 0.22 & \multirow{3}{*}{-} & L_02-L_01 & 0.7802 \\
\hline & & & & & & & & L_03-L_01 & 0.5672 \\
\hline & Residuals & 92 & 0.13657 & 0.001484 & & & & L_03-L_02 & 0.7804 \\
\hline \multirow{3}{*}{$\mathrm{Na}$} & layer & 2 & 0.2275 & 0.11374 & 4.25 & $0.017 *$ & \multirow{3}{*}{-} & L_02-L_01 & 0.5676 \\
\hline & & & & & & & & L_03-L_01 & 0.0517 \\
\hline & Residuals & 97 & 2.5952 & 0.02675 & & & & L_03-L_02 & $0.0076^{* *}$ \\
\hline \multirow{3}{*}{$\mathrm{K}$} & layer & 2 & 0.414 & 0.20719 & 4.95 & $0.00895 * *$ & \multirow{3}{*}{-} & L_02-L_01 & 0.1236 \\
\hline & & & & & & & & L_03-L_01 & $0.0023 * *$ \\
\hline & Residuals & 97 & 4.058 & 0.04183 & & & & L_03-L_02 & 0.1399 \\
\hline \multirow{3}{*}{$\mathrm{Ca}$} & laver & 2 & 3236 & 16180 & 972 & $0000143 * * *$ & \multirow{3}{*}{-} & L_02-L_01 & $0.0157 *$ \\
\hline & & 2 & & & & 0.000143 & & L_03-L_01 & $2.7 \mathrm{e}-05^{* * *}$ \\
\hline & Residuals & 97 & 161.54 & 1.665 & & & & L_03-L_02 & 0.0775 \\
\hline \multirow{3}{*}{ DHA } & laver & 2 & 28949243 & 14474621 & 17.60 & $3.02 \mathrm{e}-07 * * *$ & \multirow{3}{*}{$3.464737 \mathrm{e}-05$} & L_02-L_01 & $0.00089 * * *$ \\
\hline & Tayer & 2 & 20949243 & $144 / 4021$ & 17.00 & & & L_03-L_01 & 4.6e- $08 * * *$ \\
\hline & Residuals & 97 & 79791216 & 822590 & & & & L_03-L_02 & $0.02546^{*}$ \\
\hline \multirow{3}{*}{ Availp } & laver & 2 & 22.94 & 11.468 & 18.23 & $1.91 \mathrm{e}-07 * * *$ & \multirow{3}{*}{$3.293085 \mathrm{e}-06$} & L_02-L_01 & $0.01776^{*}$ \\
\hline & & & & & & $1.910-01 / \mathrm{s}$ & & L_03-L_01 & $5.5 \mathrm{e}-08^{* * *}$ \\
\hline & Residuals & 97 & 61.04 & 0.629 & & & & L_03-L_02 & $0.00098^{* * *}$ \\
\hline
\end{tabular}

Signif. codes: ‘***’.001 ‘**’.01 ‘*0.05

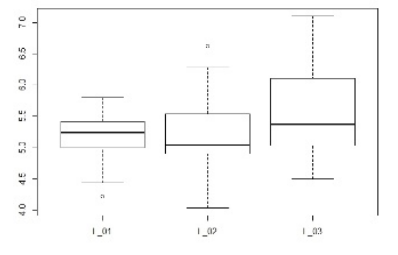

$\mathrm{pH}$

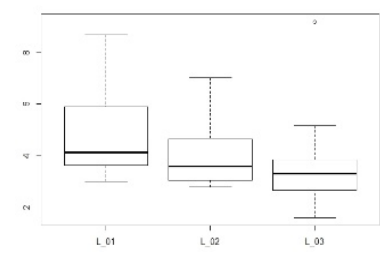

$\mathrm{Ca}$

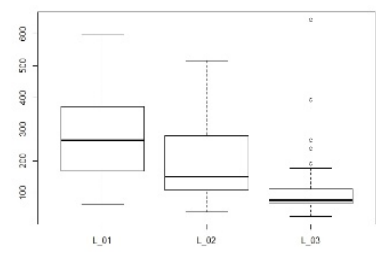

$\mathrm{EC}$

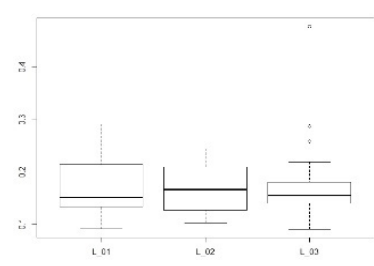

$\mathrm{Mg}$
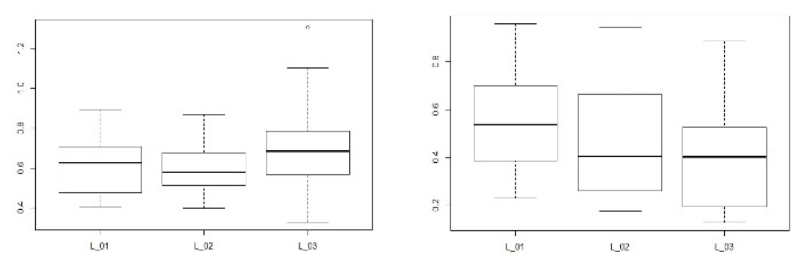

$\mathrm{Na}$

K

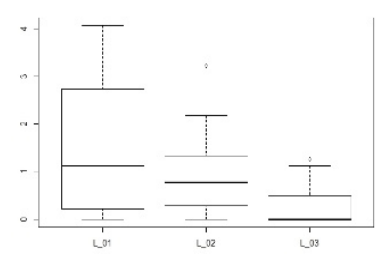

Availp

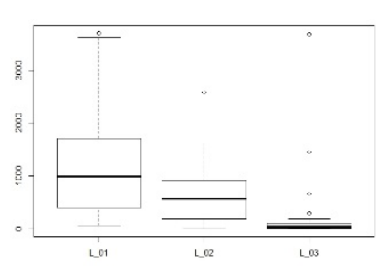

DHA

Fig. 7. Dendrogram of results of soil chemical characteristics in each soil layer (L_01: Top Layer, L_02: Surface Layer, L_03: Subsoil Layer. 
Table 5. Depth structure of the whole of Junam wetland and the change in the Nelumbo nucifera community area

\begin{tabular}{|c|c|c|c|c|c|c|}
\hline \multirow{2}{*}{ Water depth (m) } & \multicolumn{2}{|c|}{2015} & \multicolumn{2}{|c|}{2017} & \multicolumn{2}{|c|}{ Total area } \\
\hline & Area $\left(\mathrm{m}^{2}\right)$ & Percentage (\%) & Area $\left(\mathrm{m}^{2}\right)$ & Percentage (\%) & Area $\left(\mathrm{m}^{2}\right)$ & Percentage (\%) \\
\hline$\langle 1.0$ & $140,413.26$ & 2.81 & $374,000.32$ & 7.48 & $1,028,390.46$ & 20.56 \\
\hline $1.0-1.2$ & $136,739.64$ & 2.73 & $213,510.45$ & 4.27 & $501,380.24$ & 10.02 \\
\hline $1.2-1.4$ & $282,385.50$ & 5.64 & $455,868.87$ & 9.11 & $614,136.87$ & 12.28 \\
\hline $1.4-1.6$ & $309,095.03$ & 6.18 & $631,668.07$ & 12.63 & $981,706.37$ & 19.62 \\
\hline $1.6-1.8$ & $51,888.29$ & 1.04 & $219,910.25$ & 4.40 & $771,138.19$ & 15.41 \\
\hline $1.8-2.0$ & $7,529.07$ & 0.15 & $29,220.90$ & 0.58 & $165,208.65$ & 3.30 \\
\hline $2.0-2.2$ & $6,611.43$ & 0.13 & $15,830.72$ & 0.32 & $52,221.75$ & 1.04 \\
\hline $2.2-2.4$ & $6,916.80$ & 0.14 & $13,020.99$ & 0.26 & $29,729.30$ & 0.59 \\
\hline $2.4-3.0$ & $19,803.83$ & 0.40 & $39,754.26$ & 0.79 & $96,110.60$ & 1.92 \\
\hline$>3.0$ & $2,142.81$ & 0.04 & $8,017.68$ & 0.16 & $54,151.81$ & 1.08 \\
\hline etc. & - & - & - & - & $708,613.37$ & 14.16 \\
\hline Total & $963,525.66$ & 19.26 & $2,000,802.51$ & 39.99 & $5,002,787.61$ & 100.00 \\
\hline
\end{tabular}

\section{Trends in the changes in the $N$. nucifera community distribution}

The spreading tendency of $N$. nucifera community was found to increase slowly at the beginning of its development, and then increase rapidly over time, mainly in shallow waters. In Junam Reservoir, N. nucifera occurred around 2007, and was only observed there, with an area of about $38,426 \mathrm{~m}^{2}$ $(0.8 \%)$ in 2009. After that, 203,556 $\mathrm{m}^{2}(4.2 \%)$ in 2011 and $342,737 \mathrm{~m}^{2}(7.0 \%)$ in 2013 , increased to $554,674 \mathrm{~m}^{2}(11.08 \%)$ in 2014. In 2015, the total coverage was $963,525.66 \mathrm{~m}^{2}$ $(19.26 \%)$ of the entire reservoir, which is a 2-fold escalation in comparison with 2014; in 2017, it corresponded to $39.99 \%$ of the total area, which is a more than 2-fold expansion in comparison to 2015 (Table 6, Fig. 9). This increase is presumed to be related to internal and external factors as well as seasonal changes in water depth. It is determined that continuous monitoring is needed to identify the cause of such a rapid increase.

When each reservoir was examined, Junam reservoir showed coverages of $1.4 \%, 7.4 \%, 12.5 \%, 18.0 \%$ and $30.6 \%$ for 2009 , 2011, 2013, 2014 and 2015, respectively, close to a 22-fold rise over the 6 years. In 2017, coverage reached approximately $60 \%$, a 2 -fold increase in just 2 years. As such, it was anticipated that a continued increase would result if the reservoir was left unattended. In Sannam reservoir, there were coverages of 7.8\% and $13.34 \%$ in 2014 and 2015, an approximately 2fold expansion in just a year. Moreover, the coverage elevated to $35.27 \%$ in 2017 , which is an approximately 2.5 -fold rise in

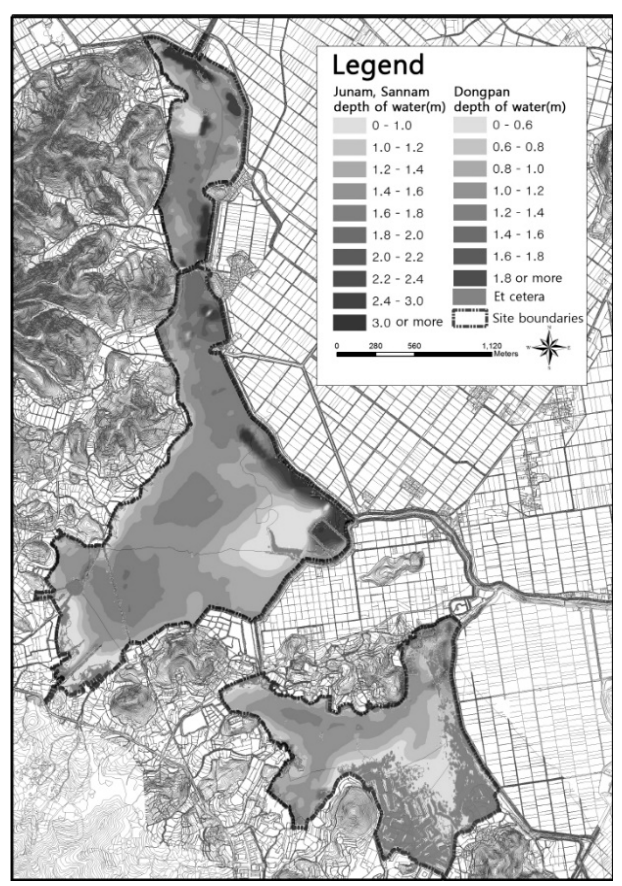

Fig.8. Depth structure map of the whole of Junam wetland.

Table 6. The changing trend of Nelumbo nucifera community area by year

\begin{tabular}{cccccc}
\hline Contents & $\begin{array}{c}\text { Junam } \\
\text { reservoir }\end{array}$ & $\begin{array}{c}\text { Dongpan } \\
\text { reservoir }\end{array}$ & $\begin{array}{c}\text { Sannam } \\
\text { reservoir }\end{array}$ & Total \\
\hline \multirow{2}{*}{2014} & Area $\left(\mathrm{m}^{2}\right)$ & 494,737 & 7,411 & 52,526 & 554,674 \\
& Percentage (\%) & 18.0 & 0.5 & 7.8 & 11.08 \\
2015 & Area $\left(\mathrm{m}^{2}\right)$ & $862,282.89$ & $9,948.30$ & $91,294.47$ & $963,525.66$ \\
& Percentage (\%) & 31.85 & 0.62 & 13.34 & 19.26 \\
\multirow{2}{*}{2017} & Area $\left(\mathrm{m}^{2}\right)$ & $1,619,829.44$ & $139,607.16$ & $241,365.91$ & $2,000,802.51$ \\
& Percentage $(\%)$ & 59.83 & 8.67 & 35.27 & 39.99 \\
\hline
\end{tabular}


comparison to 2015. In Dongpan reservoir, although the coverages were only $0.5 \%$ and $0.62 \%$ in 2014 and 2015 , respectively, it rose rapidly, to show a 12-fold increase in 2017 (8.67\%) in comparison to 2015. Although the area was smaller in comparison to other reservoirs, the water depth was shallow, so the potential for rapid diffusion was high.

\section{Management method}

Looking at the distribution characteristics of $N$. nucifera community based on the results of the analysis of water depth, precipitation, soil accumulation, and water quality in Junam wetland, precipitation in May and June has decreased since 2012. The process of constant rainfall restoring the water level has disappeared. Also, there was no artificial soil deposition, except for areas where water flow was stagnant among the $N$. nucifera community established in 2009. The $N$. nucifera community had already occupied the shallow water and then spread to the deep water, but the overall water quality in these areas was maintained at a poor level. Eventually, the $N$. nucifera community is highly likely to spread due to the change in rainfall pattern and the shallower water depth during the growing season, which also affects the water quality. Through the analysis of whether or not the sediment was deposited, it was confirmed that artificial sedimentation did not lower the water level of the reservoir, so management needs to focus on removing the already spread $N$. nucifera community and controlling the water level in the busy season, and this was suggested in the control plan.

Meanwhile, the Junam wetland is an important place not only as a habitat for wildlife but also for the livelihood of fishermen, so it is essential to balance conservation and use. In addition, it would be desirable to exclude total removal through dredging, an approach which has failed in other areas, in consideration of the rate of spread, water level fluctuations, and the impact on the habitat and environment for $N$. nucifera community management. Fig. 10 presents the timing of removal, removal method and frequency, water level maintenance, and submersion period. The period of growth of $N$. nucifera in the survey site overlaps with the busiest farming season in which water is supplied to the rice paddies, thereby lowering the water level in the reservoirs and establishing an environment appropriate for the growth and development of $N$. nucifera. As such, it is desirable to remove them during June-August, which is the growth period of the emergent leaves, by using the method of removing the portions $20-50 \mathrm{~cm}$ below the water surface 2-3 times for 2 years in succession or elevating the water level by $0.5-1.0 \mathrm{~m}$ after mowing. Regarding the elevation in the

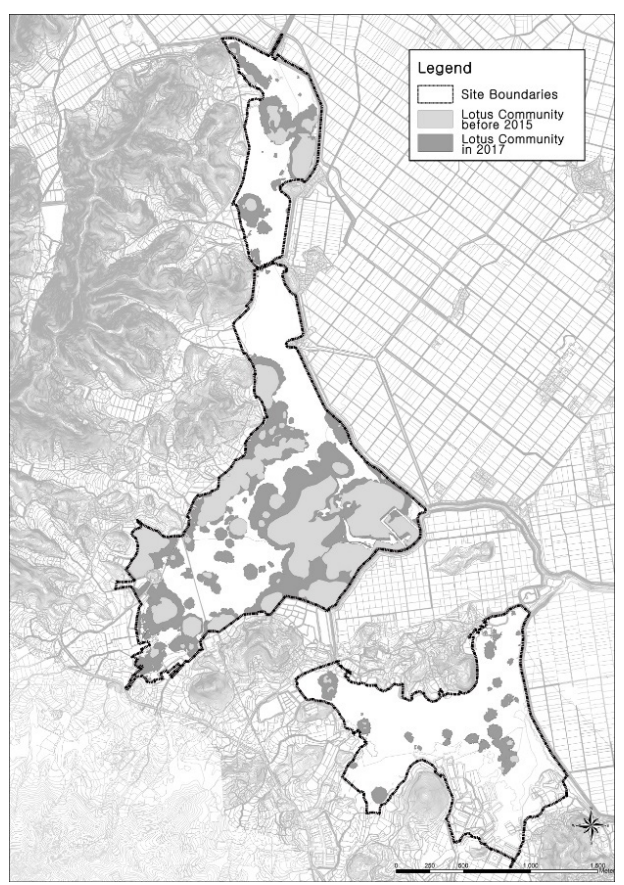

Fig. 9. Trends of Junam wetland's Ne/umbo nucifera community between 2015 and 2017.

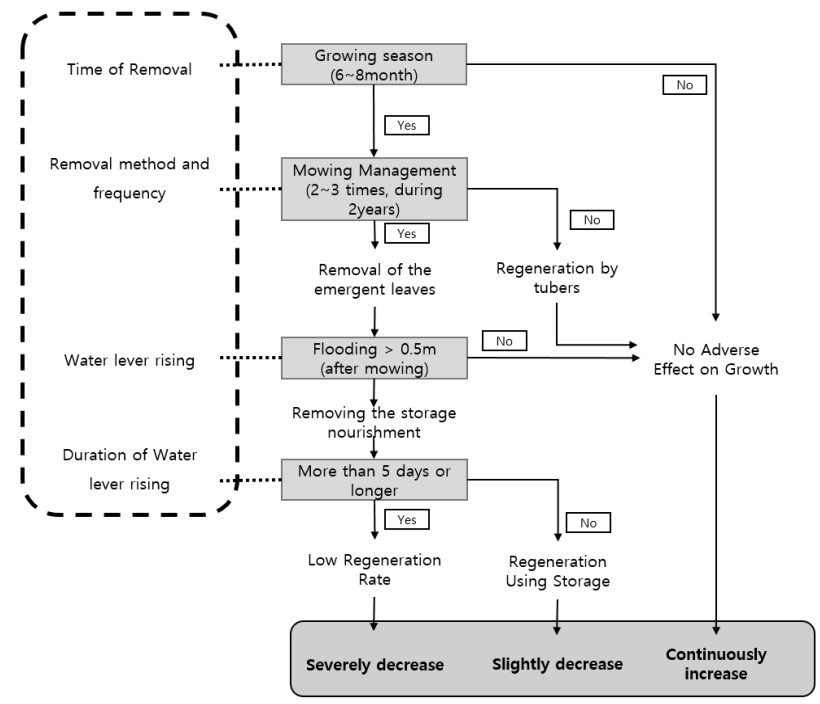

Fig. 10. Water level and mowing management of the Ne/umbo nucifera community of Junam wetland. 
water level and the period of such an increase, it is desirable to elevate the water level by more than $0.5 \mathrm{~m}$ from the stump removed and maintain it for a minimum of 5 days in order to remove nutrients in the tuber. However, as Junam wetland is a wintering site for wild birds and since ducks, Anser spp., and C. columbianus, etc. begin to arrive from early October, this period needs to be avoided.

\section{Discussion}

The $N$. nucifera flower symbolizes innocence, nobility, and enlightenment in East Asia, and is used as a visual pattern to represent Buddhism and the Principle of YinYang and Five Elements (Rho et al., 2018). In addition, the leaves, stems, and lotus root can be used for food, so they are also cultivated for income by farmers in the southern regions (Choi, 2009). Even now, from a practical point of view, the $N$. nucifera flower is closely related to our daily life to the extent that studies related to the commercial use of the flower pattern and the aesthetic and medical use of the extract are underway (Jung, 2004; Moon et al., 2018; Hong and Kim, 2010; Jeong et al., 2017). Due to the commercial value of the $N$. nucifera, it can achieve the practical purpose of promoting tourism during the flowering period and the utilization of leaves, stems and roots in other seasons. For this reason, its distribution has been expanding throughout the country as it is planted for ornamental purposes mainly in reservoirs and lakes. Although such diffusion has achieved some effect in terms of tourism and profit, it is time to take measures to control its spread, because it can cause unexpected problems such as disturbance of wetland ecosystems and damage to habitats at an unpredictable rate.

This study was conducted to discern the distribution characteristics and to propose methods of controlling the proliferation of $N$. nucifera, which can induce degradation of the habitat for wildlife due to its rapid dispersion, as an environmental factor that can adversely affect the Junam wetland ecosystem. Junam wetland, located in the southern part of Korea, is the best place for population growth as Kim (2008) stated that the average daily temperature is $15{ }^{\circ} \mathrm{C}$ or higher for more than 6 months, and in July to August, the peak growth period, there are many sunny days with high temperatures. Therefore, the possibility of its spread is high if management is not performed at an appropriate level. In addition, in the case of lotus clusters, with respect to the growth depth, it was said that around $20 \mathrm{~cm}$ was suitable for food use (Kang, 2006). However, in natural wetlands, the optimal growth conditions are around $1.5 \mathrm{~m}$, but research findings suggest that it can grow up to $3 \mathrm{~m}$ (Unni, 1971; Kuni and Maeda, 1982; Nohara and Kimura, 1997), so it was predicted that the water would spread rapidly around shallow Dongpan reservoirs.

Based on the comparison of the differences in the water quality with the aquatic plant community to check the ecological effects of $N$. mucifera community, it was difficult to discuss the quantitative value of the trends. This is presumed to be related to the fact that while aquatic plants play the role of a storage sink that absorbs large quantities of phosphorous and nitrogen from the drainage system during their growth stage, they discharge the nutrients they absorb back to the drainage system during the period of withering (Kadlec and Wallace, 2009). It has been reported that in addition to the processes of sedimentation, adsorption and denitrification, aquatic plants also remove phosphorous and nitrogen through direct absorption (Brix, 1997). Ultimately, while the regions with a $N$. nucifera community distribution were maintained at a poor water quality level due to the water stagnation, it was determined that the regions with no distribution of $N$. mucifera did not show a significant difference due to re-influx of nutritional substances into the water through repetition of floating, floating leaves and growth and withering of submerged plants. Despite the fact that water was supplied to the reservoirs due to the overflowing of the Nakdong river in the past, the water flow is relatively stagnant, with the water level currently maintained through rainfall or artificial supply for agricultural use, and it was confirmed that there is almost no sedimentation of organic matters.

With respect to water quality, aquatic plants have been studied for their removal of phosphorus, nitrogen, etc. through direct absorption in addition to sedimentation, adsorption and denitrification processes (Brix, 1997). Ultimately, while the regions with $N$. mucifera community distribution maintained a poor level of water quality due to the water's stagnation, it was determined that the regions with no distribution of $N$. nucifera did not display a significant difference due to re- 
influx of nutritional substances into the water through repetition of floating, floating leaves and growth and withering of submerged plants. This is consistent with that aquatic plants act as a sink for absorbing phosphorus and nitrogen from the water system during the growing season, but release the absorbed nutrients back to the water system during the dead period (Kadlec and Wallace, 2009). In spite of the fact that water was supplied to the reservoirs by the previous overflowing of Nakdong river and the water flow is now relatively stagnant with the water level being maintained through rainfall or artificial supply for agricultural use, it was confirmed that there is almost no sedimentation of organic matters. As a result, comparing the soil conditions with the planting base of aquatic plants in artificial wetlands suggested by Kim (1999), it was judged that there would be no major problems in growth except for the available phosphoric acid.

In aquatic plants, including the $N$. nucifera, heterophylly of leaves within the same plant is common (Sculthorpe, 1967), and this strategy plays an important role in dominance (Bini et al. , 1999). In N. nucifera, mature floating leaves die after being submerged, but emergent and growing leaves grow up to $25 \mathrm{~cm}$ per day, so it is difficult to remove them (Nohara and Kimura, 1997). In addition, the impact of water level change on the growth of $N$. nucifera varies according to the number of floods, and the ratio of floating and emergent leaves is low in late September, which is said to be in preparation for the next growth season (Tsuchiya and Nohara, 1989). Grime (1979) compared the cost of producing emergent leaves with the benefits obtained from emergent leaves during the growing season, and said that in deep sites, the cost of petiole formation was minimized and survival was achieved by making floating leaves.

On the other hand, plants that thrive in wetlands have developed rhizomes that enable them to grow in permanently saturated moisture and soil, and aerenchyma to supply oxygen to the roots (Nyman et al., 1993). Germination and growth of wetland plants are not only caused by water level fluctuations, habitat nutrient levels, management changes, and mechanical scraping (Hroudova and Zakravsky, 1999), but also by changes in the water cycle system such as retention time and depth. This has been said to be a key factor controlling growth. Specifically, water level and flooding affect the composition of wetland plant communities (Brock et al,
1987; Nohara, 1996), but the intensity, frequency, and length of flooding mainly affect primary production (Tsuchiya and Nohara, 1989; Nohara and Tsuchiya 1990; Megonigal and Day, 1992). Heterophylly of $N$. nucifera leaves and short-term growth after submersion of young leaves (Nohara and Kimura, 1997) are factors that make management difficult.

According to studies so far, water level management, mowing management, installation of posts and removal of lotus roots have been suggested as management methods for the N. nucifera community (Nohara and Tsuchiya, 1990; Shimada et al., 2017, Ashizawa et al., 2015; Sale and Wetzel, 1983). Extreme approaches used in small ponds such as dredging and pile installation were not desirable for the Junam wetland because of its role of habitat for biodiversity, so they were excluded. As a result, management of $N$. nucifera community in Junam wetland requires the same method as cutting it from 20 to $50 \mathrm{~cm}$ below the proposed water surface to remove cattails, causing an oxygen deficiency (Sale and Wetzel, 1983). In addition, it was judged that flooding through the rise of the water level should be accompanied by an artificial flooding effect. Therefore, in the management of an $N$. mucifera community, the distribution of lotus flowers is limited to a depth of 3 to $5 \mathrm{~m}$. In the case of harvest leaves, it has been shown that the lotus leaves die if submerged at a water level of $50 \mathrm{~cm}$ or more and for 5 days or more after they occur (Nohara and Tsuchiya, 1990). However, the method of elevating the water level is difficult to apply because it can impart effects on the embankment. Therefore, it was confirmed by Shimada et al. (2017) that concurrent execution of the water level management and mowing is effective. It has been proven by Ashizawa et al. (2015) that removal of $N$. nucifera 2-3 times for 2 years in succession can produce the desired effects in the $3^{\text {rd }}$ year. When $N$. nucifera is removed at a depth of more than $20-50 \mathrm{~cm}$ from the water's surface during June to August, which is the period of aggressive growth, removal effects can be achieved by inducing oxygen deficiency in the plants (Sale and Wetzel, 1983). But in consideration of the uncertainty, as the floating leaves or young leaves can grow to $0.5 \mathrm{~m}$ or more, it was determined that elevation of the water level by more than 0.5-1.0 $\mathrm{m}$ after removal would be effective. It is determined that the installation of posts is difficult to apply due to the difficulties of installing them in a wide area, and in controlling the possibility 
of enlargement by spreading seeds. It is also deemed that removal of lotus roots is difficult to apply since it is a method excluded from the management of $N$. micifera in small wetlands within the Sajipo Marsh (Nakdong river Basin Environmental Office, 2016) due to damage to the environment and the inability to predict the effects on the habitat for the living organisms.

The $N$. mucifera community has shown a trend of expansion as it has been unattended due to its religious significance and scenic value, despite the finding that its area of coverage of reservoirs throughout the country is rising rapidly and is thus inducing damages to the habitat for the wild birds and reduction in biodiversity. Although there is no major problem with its use in urbanized regions or reservoirs irrelevant to inhabitation by wildlife, there is a significant need for control in regions with a high value as wintering sites, such as Junam wetland. However, since the control methods proposed in this study are based on those introduced in the literature and errors in the existing control methods, it is necessary to supplement the feedback process through a field demonstration. In order to control the $N$. mucifera community in wetlands that are highly valuable as habitats for living organisms in the future, there is a need to present a methodology on the basis of the results found after having concurrently executed removal and water level control.

\section{References}

Amoros, C. G. Bornette, and C.P. Henry. 2000. A vegetationbased method for ecological diagnosis of riverine wetlands. Environ. Manag. 25(2):211-227. https://doi.org/10.1007/ s002679910017

Anderson, J.T. and L.M. Smith. 1998. Protein and energy production in playas: implications for migratory bird management. Wetlands 18:437-446. https://doi.org/10.1 007/BF03161536

Ashizawa, J. M. Hoshi, Y. Fujimoto, and T. Shimada. 2015. Experimental inhibition methods of a Nelumbo nucifera community using cutting equipment in a lake. IzunumaUchinuma Wetl. Res. 9:61-70.

Bellrose, F.C. 1980. Ducks, geese and swans of North America. Washington, D.C.: Wildlife Management Institute.

Bellrose, F.C. S.P. Havera, F.L. Paveglio Jr., and D.W.
Steffeck. 1983. The fate of lakes in the Illinois River Valley. Illinois Nat. Hist. Surv. Biol. Notes 119:3-27. https://www.ideals.illinois.edu/

Bini, L.M., S.M. Thomaz, K.J. Murphy, and A.F.M. Camargo (1999) Aquatic macrophyte distribution in relation to water and sediment conditions in the Itaipu reservoir, Brazil. Hydrobiologia 415:147-154.

Brix, H. 1997. Do macrophytes play a role in constructed treatment wetlands ? Water Sci. Technol. 35(5):11-17. https://doi.org/10.1016/S0273-1223(97)00047-4

Brock, M.A., D.L. Nielsen, R.J. Shiel, J.D. Green, and J.D. Langley. 2003. Drought and aquatic community resilience: the role of eggs and seeds in sediments of temporary wetlands. Freshw. Bio. 48:1207-1218. https://doi.org/10. 1046/j.1365-2427.2003.01083.x

Castelli, R.M., J.C. Chambers, and R.J. Tausch. 2000. Soilplant relations along a soil-water gradient in great basin riparian meadows. Wetlands 20(2):251-266. https://doi.or g/10.1672/0277-5212(2000)020[0251:SPRAAS]2.0.CO;2

Changwon-si. 2018. A white book on Changwon. Changwon-si, Gyeongnam, Korea.

Choi, G.L. 2009. Study on taxonomic characteristics of collected Nulembo nucifera Gaertner. Doctoral Dissertation, Suncheon National University, Korea.

GRETeC. 2015. Life breathing Junam reservoir comprehensive management plan. GRETeC, Changwon-si, Korea.

Grime, J.P. 1979. Plant strategies and vegetation processes. New York. USA.: John Wiley \& Sons, LTD.

Hahm, K.H. 1997. A report on birds designated as natural monuments recorded in Junam and Dongpan reservoir of Korea, 1988-1996. Bull. Korea Ins. Ornithol. 6(1): 63-71.

Hahm, K.H. 2000. Studies on the variation of birds within the Junam reservoir in the last ten years (1989-1998). J. Basic Sci. Res. Inst. 14:73-84.

Hahm, K.H. and S.W. Son. 1998. Comparison of distribution of birds at the Upo wetland and Junam reservoirs in Korea. J. Basic Sci. Res. Inst. 12:261-273.

Hong, J.H. and H.K. Kim. 2010. The development of woman's hanbook textile design applying Korea traditional lotus pattern. Res. J. Costume Cult. 18(5):908-922.

Hong, S.H. and M.Y. An. 2016. Relationship between the behavior pattern of wintering cygnus and distribution 
of Nelumbo nucifera. Korean J. Environ. Ecol. 30(5): 848-856. https://doi.org/10.13047/KJEE.2016.30.5.848

Hroudová, Z. and P. Zákravský. 1999. Vegetation dynamics in a fishpond littoral related to human impact. Hydrobiologia 415:139-145. https://doi.org/10.1023/A:1003813129683

Illinois Wildlife Habitat Commission Report. 1985. The crisis of wildlife habitat in Illinois today. Springfield, IL. USA: Illinois Department of Conservation.

Jeong, H.J., Y.G. Park, T.W. Jang, D.W. Kim, J.B. Jeong, and J.H. Park. 2017. Inhibition effects on oxidative DNA damage and anti-inflammatory effects of Nelumbinis Flos. Kor. J. Herbol. 32(3):45-53. http://dx.doi.org/10.6116/kj h.2017.32.3.45

Jung, J.S. 2004. The development of textile design and the manufacture of cultural merchandise by using lotus flower patterns ( II ). J. Kor. Soc. Cloth. Ind. 6(4):421-426.

Kadlec, R.H. and S.D. Wallace. 2009. Treatment wetlands (2nd ed.). Boca Raton, FL, USA: CRC Press.

Kang, M.S. 2006. Lotus tea that eliminates toxins from body. Seoul, Korea: Hanam Publishing Company.

Kim, E.J. 2008. Wild flowers and resource plants in Korea. Seoul, Korea: Seoul University Press.

Kim, H.Q. 1999. A study on the criteria of planting substrate for hydrophytes in creating man-made wetland. Master's thesis, Seoul National University, Seoul, Korea

Kim, K.I. 2012. The present condition and the usage increase of lotus (Nelumbo. nucifera). Master's thesis, Korea University, Seoul, Korea.

King, R.S., K.T. Nunnery, and C.J. Richardson. 2000. Macroinvertebrate assemblage response to highway crossings in forested wetlands: implications for biological assessment. Wetl. Ecol. Manag. 8:243-256. https://doi.org/10.1023/ A:1008479316066

Kunii, H. and K. Maeda. 1982. Seasonal and long-term changes in surface cover of aquatic plants in a shallow pond, Ojaga-ike, Chiba, Japan. Hydrobiologia 87:45-55. https://doi.org/10.1007/BF00016661

Li, Y., T. Smith, P. Svetlana, J. Yang, J.H. Jin, and C.S. Li. 2014. Paleobiogeography of the lotus plant (Nelumb onaceae: Nelumbo) and its bearing on the paleoclimatic changes. Palaeogeogr. Palaeoclimatol. Palaeoecol. 399:2 84-293. https://doi.org/10.1016/j.palaeo.2014.01.022

Lindenmayer, D.B. and G.E. Likens. 2018. Effective eco- logical monitoring. Australia: CSIRO Publishing.

McConnell, D.L. and D.E. Samuel. 1985. Small mammal and avian populations utilizing cattail marshes on reclaimed surface mines in West Virginia (pp. 329-336). In R.P. Brooks, D.E. Samuel, and J.B. Hill (eds.). Wetlands and Water Management on Mined Lands-Proceedings of a Conference. The Pennsylvania State University, University Park, PA, USA.

Megonigal, J.P. and F.P. Day. 1992. Effects of flooding on root and shoot production of bald cypress in large experimental enclosures. Ecology 73:1182-1193.

Mitch, W.J. and J.G. Gooselink. 2000. The values of wetlands: importance of scale and landscape setting. Ecol. Econ. 35(1):25-33.

Moon, E., J. Jeon, G. Lee, M. Baik, and D.W. Lee. 2018. Effect of isoquercitrin-containing Nelumbo nucifera leaves extract on skin wrinkle improvement. J. Soc. Cosmet. Sci. Korea 44(2):191-200. http://dx.doi.org/10.15230/S CSK.2018.44.2.191

Myers, J.P., R.I.G. Morrison, P.Z. Antas, B.A. Harrington, T.E. Lovejoy, M. Sallaberry, S.E. Senner, and A. Tarak. 987. Conservation strategy for migratory species. Am. Sci. 75:19-26.

Nakdong River Basin Environmental Office. 2016. The first year project for fundamental elimination of lotus (Nelumbo nucifera) community, Sajipo (2015).

Naugle, D.E., R.R. Johnson, M.E. Estey, and K.F. Higgins. 2000. A landscape approach to conserving wetland bird habitat in the Prairie Pothole Region of Eastern South Dakota. Wetlands 20:522-604. https://doi.org/10.1672/0 277-5212(2000)020[0588:ALATCW]2.0.CO;2

Nohara, S. 1996. Growth of the Indian lotus (Nelumbo nucifera Gaertn.) and the influence of tuber density on foliage structure and biomass. Jpn. J. Limnol. 57(3):235-243.

Nohara, S. and M. Kimura. 1997. Growth characteristics of Nelumbo nucifera Gaertn. in response to water depth and flooding. Ecol. Res. 12:11-20.

Nohara, S. and T. Tsuchiya. 1990. Effects of water level fluctuation on the growth of Nelumbo nucifera Gaertn. in lake Kasumigaura, Jpn. Ecol. Res. 5:237-252. https:// doi.org/10.1007/BF02346994

Nuri Environmental Technology Center. 2014. Research project for fundamental elimination of Upo wetland community. 
Nyman, J.A., R.D. De Laune, H.H. Roberts, and W.H. Patrick, Jr.. 1993. Relationship between vegetation and soil formation in a rapidly submerging coastal marsh. Mar. Ecol. Prog. Ser. 96:269-279.

Park, K.H. J.Y. Seo, and J.H. You. 2012. Analysis on characteristics of aquatic ecosystem environment in Junam reservoir. Korean J. Environ. Ecol. 26(5):694-706.

Rho, J.H., D.Y. Lee, and S.H. Choi. 2018. An ecological aesthetics and symbolism of the Seonghyelsa Nahanjeon floral lattice with patterns of lotus pond scenery. J. Korean Inst. Tradit. Landsc. Archit. 36(3):160-171. https://doi.o $\mathrm{rg} / 10.14700 /$ KITLA.2018.36.3.160

Sale, P.J.M. and R.G. Wetzel. 1983. Growth and metabolism of Typha species in reaction to cutting treatment. Aquat. Bot. 15:321-334. https://doi.org/10.1016/0304-3770(83) 90001-3

Sather, J.H. and R.D. Smith. 1984. An overview of major functions and values. FWS/OBS-84/18. Washington, D.C.: United States Department of the Interior, Fish and Wildlife Service, Division of Biological Services, Western Energy and Land Use Team.
Sculthorpe, C.D. 1967. The biology of aquatic vascular plants. Science 160(3824):179. https://doi.org/10.1126/science. 160.3824.179-a

Shimada, T. T. Ueda, M. Hoshi, and A. Mori. 2017. Effects of water level on habitat selection by foraging Whooper Swans. Bird Res. 13:S5-S9.

Tiner, Jr., R.W. 1999. Wetland Indicators: a Guide to Wetland Identification, Delineation, Classification, and Mapping. Boca Raton, FL, USA: Lewis Publishers.

Tsuchiya, T. and S. Nohara. 1989. Growth and lifespan of the leaves of Nelumbo micifera GAERTN. in Lake Kasumigaura, Japan. Aquat. Bot. 36:87-95.

Unni, K.S. 1971. An ecological study of the macrophytic vegetation of the Doodhadhari Lake, Raipur, M.P., India 1. Distribution and seasonal change in aquatic plants. Hydrobiologia 38:139-155. https://doi.org/10.1007/BF0 0016370

Van der Valk, A. 2012. The Biology of Freshwater Wetlands. New York. USA: Oxford university press.

Weller, M.W. 1999. Wetland birds: Habitat resources and conservation implications. Cambridge, UK: Cambridge Uni. Press. 